\title{
Analysis of Socioeconomic Variables Influencing Rice Production in Calabar Agricultural Zone of Cross River State, Nigeria
}

\author{
${ }^{1}$ CAROLINE LINUS ABOH Ph.D, ${ }^{2}$ EREMI, EMMANUEL OHARA Ph.D \\ and ${ }^{3}$ AYA COMFORT FELIX \\ Department of Agricultural Extension And Rural Sociology \\ University of Calabar, \\ Calabar - Nigeria.
}

\begin{abstract}
The main focus of this research was to analysis the socioeconomic variables influencing rice production in the Calabar Agricultural Zone of Cross River State. The study specifically examined the influence of farmers sex, age, marital status, level of education, farm size, family size, income, labor and road access to credit, etc on rice production in the area. The study adopted survey design, data were obtained with the aid of a validated structured questionnaire and analyzed using mean, frequency count percentages and probit regression model. A total of 110 respondents were randomly selected from 332 population of registered rice farmers in the area. The results of the analysis revealed that rice production in the area was defined by the cost of labor, farmers access to credit facilities, income, level of education, farm and family size and marital status etc. It was, therefore, recommended among others that government should provide credit facilities to the farmers and improve adult literacy programs in rural farming communities.
\end{abstract}

Key words: Socioeconomic Variables, Rice Production, Calabar Agricultural Zone.

\section{INTRODUCTION}

Rice is one of the most widely consumed staple food crops in sub-Saharan Africa, and Nigeria has been adjudged the largest producer of rice in the West Africa sub-region. It is estimated that the total area under cultivation of rice in Nigeria has consistently increased from 45,000 hectares in the 1980s to approximately 200,000 hectares in 2015 (Economic News Update, 2015). Nigeria's estimated aggregate rice production has also increased from 600,000 tones to 3.3 million tones within the same period.

Rice is largely regarded as neutral good, whose demand remains the same regardless of market price dynamics, it is the most daily consumed cereal in homes, eateries and occasion. The wide acceptance of rice (Oryza sativa) is to a large extent associated with its plausible multiplier effect-beside merely being utilized as food, increased rice production can transform peasant households into commercial producers and job creators rather than white-collar job seekers. Similarly, rice has continued to serve as foreign exchange and revenue generating instrument for many countries that have invested in its production. Countries such as Thailand, China and others have reaped the dividend of sustained investment in rice production.

Unfortunately, despite Nigeria possessing enormous potentials in terms of land and human capital resources suitable for rice production, the country has not lived up to its potentials to produce sufficient quantity of rice to feed the teeming population. A wide range of narratives have been put forward to rationalise Nigeria's struggles in rice production. There is a gross lack of access to production resources, rice farmers require modern inputs and equipment, farmers need unrestrained access to credit facilities and structured market so that farmers are not exploited (Gregory, 2010). There is also an alarming lack of technical skills among particularly rural peasant rice farmers, coupled with high level of illiteracy, which have cooperated to undermine efforts and calls to improve production to ensure food security.

The continuing influence of cultural and traditional practices surrounding land allocation and access to production resources presents a complex network of challenges to young and willing farmers to engage in rice production. Historically, gender stereotypes, political and income- related factors have conspired to compromise initiatives to enhance rice production. A large segment of rural rice farming populations lacks access to viable transport system and communication infrastructure to access modern innovations (Kategoki). 
Harris (2015) identifies high cost of labour, increasing rural-urban migration, lack of incentives, lack of political will, wide-spread incidence of poverty among farmers, and restrictions on access to land etc as some of the factors militating against rice production in Nigeria. Cross River State is one of the states in Nigeria where rice is produced on a commercial scale. In particular, rice has historically served both domestic and commercial purposes in the area. However, the volume of rice produced in the state has hardly matched the enormous natural and human endowments of the area. A number of theorizing has been used to account for the short-falls in the state's rice production, with some rare empirical engagements to rationalise our rice production situation.

It is against the foregoing that this research was carried out, to examine the socioeconomic variables influencing rice production in Calabar Agricultural Zone of Cross River State.

\section{GENERAL OBJECTIVE}

The general objective of this study was to analyze the influence of socioeconomic variables on rice production in Calabar Agricultural Zone of Cross River State, Nigeria.

\section{METHODOLOGY}

The study adopted a survey design. The study was carried out in the Calabar Agricultural Zone of Cross River State. The population of the study comprised 382 registered rice farmers, consisting of 268 men and 114 women. The study adopted a three stage random sampling technique; stage one involved a random selection of Biase, Odukpani and Akpabuyo out of the seven (7) Local government areas in the Calabar Agricultural Zone. Stage two involved the random selection of three intensive rice producing communities from the local government areas sampled- thus bringing the total to nine (9) communities. Stage three involved a random selection of one hundred and ten (110) respondents (registered rice farmers) from the communities selected.

The instrument used for data collection was a validated 58 -item structured questionnaire, modeled on five - point Likert scale. The questionnaire was sub-divided in the two sections based on the specific objectives of the study. Section A was designed to elicit information on the socioeconomic characteristics of the respondents, while section B was structured to address other research variables. The questionnaire was administered by the researchers, having been tested for reliability using the test retest technique. Data obtained were analyzed using descriptive statistics such as mean, frequency count and percentages, as well as the probit regression model. The regression model was specified as follows:

\begin{tabular}{lll}
$\mathrm{Y}=\mathrm{f}\left(\mathrm{x}_{1}, \mathrm{x}_{2}, \mathrm{x}_{3}, \mathrm{x}_{4}\right.$ & - & $\left.-\mathrm{x}_{\mathrm{n}} \mathrm{U}\right)$ \\
\multicolumn{2}{l}{ Where; } & $\mathrm{y}=$ Dichotomous dependent variable - Rice production \\
$\mathrm{X}_{1}-\mathrm{x}_{\mathrm{n}}=$ & Independent variables, expressed as \\
$\mathrm{X}_{1}$ & $=$ & Sex \\
$\mathrm{X}_{2}$ & $=$ & Age \\
$\mathrm{X}_{3}$ & $=$ & Marital status \\
$\mathrm{X}_{4}$ & $=$ & Level of education \\
$\mathrm{X}_{5}$ & $=$ & Family size \\
$\mathrm{X}_{6}$ & $=$ & Farm size \\
$\mathrm{X}_{7}$ & $=$ & Farming experiences \\
$\mathrm{X}_{8}$ & $=$ & Annual income \\
$\mathrm{X}_{9}$ & $=$ & Labour \\
$\mathrm{U}$ & $=$ & error term
\end{tabular}

\section{RESULTS AND DISCUSSION}

Table 1. Distribution of respondents' socioeconomic characteristics

\begin{tabular}{lll}
\hline Variables & Frequencies & Percentage \\
\hline Sex & & \\
Male & 80 & 72.73 \\
Female & 30 & 27.27 \\
Total & 110 & 100 \\
& & \\
Age & & \\
$18-35$ years & 40 & 36.36 \\
$36-53$ years & 59 & 53.64 \\
53 years and above & 11 & 10 \\
Total & 110 & 100 \\
& & \\
\hline
\end{tabular}




\begin{tabular}{lll}
\hline Martial status & & \\
Married & 47 & 42.73 \\
Single & 32 & 29.09 \\
Divorced & 17 & 15.45 \\
Widow & 14 & 12.73 \\
Total & 110 & 100
\end{tabular}

Educational level

No formal education

Primary school

Secondary school

45.45

Tertiary institution

20.00

Total

100

Major-occupation

Farming

Civil servant

94.55

Others

104

2.73

Total

Farming experiences

1-3 years

4-10 years

11 and above

20

18.18

Total

Farm size

$<1$ hectare

1-3 hectares

29.09

4 hectares and above

0.00

Total

100

Source of loan/credit

\begin{tabular}{lll} 
Banks & 13 & 11.82 \\
Cooperative & 60 & 54.55 \\
Private lenders & 46 & 41.52 \\
Family/friends & 79 & 71.82 \\
Personal savings & 22 & 20.00 \\
Total & 110 & 100 \\
\hline
\end{tabular}

Source: Field survey, 2018

Table 2. Distribution of respondents based on effects of cost of labour on rice production in the area $\mathrm{N}=110$

\begin{tabular}{|c|c|c|c|c|c|c|}
\hline Variable & $\mathbf{S A}$ & $\mathbf{A}$ & $\mathbf{D}$ & SD & $\sum \mathbf{E X}$ & $\mathbf{X}$ \\
\hline Reduction in size of land cultivated & $80(320)$ & $21(63)$ & $9(18)$ & - & 401 & 3.65 \\
\hline Increase in cost of rice production & $79(316)$ & $30(90)$ & - & $1(1)$ & 407 & 3.7 \\
\hline $\begin{array}{l}\text { Low profit due to high cost of } \\
\text { production }\end{array}$ & $100(400)$ & $10(30)$ & - & - & 430 & 3.91 \\
\hline Reliance on only family labour & $21(84)$ & $2(6)$ & $7(14)$ & $80(80)$ & 184 & 1.67 \\
\hline $\begin{array}{l}\text { Low rice output due to reduced area } \\
\text { cultivated }\end{array}$ & $90(360)$ & $6(18)$ & $100(20)$ & $4(4)$ & 402 & 3.65 \\
\hline
\end{tabular}


International Journal of Advances in Scientific Research and Engineering (ijasre), Vol 5 (7), July-2019

Use of fewer labourers

60(276)

$30(90)$

$9(18)$

2(2)

386

3.51

Farmers are discouraged from

growing rice.

Lack of labourers in the area which

make available ones to charge very

high

Source: Field Survey, 2018.

Table 2 shows the distribution of respondents based on effect of cost of labour on rice production in the area. The results revealed that six (6) of the eight (8) effects identified recorded means scores above the cut-off X of 2.50, which implies that they were accepted by the respondents. The other two variables - reliance on only family laboour $(\overline{\mathrm{X}}=1.67)$ and farmers being discouraged from growing rice $(\bar{x}=2.31)$ scored below the 2.50 mark, which means they were rejected by the respondents. The implication of this is that even in the face of increased cost of labour, farmers will not stop growing rice and are unlikely to rely only on family labour for rice production since it is hardly sufficient. Many studies (Adepoju, 2000; Appleton et al, 2011; Awole, 2003; and Chinaka, 2015) found that when labour cost is high, it will raise the cost of production, make farmers have low profit, increase prices of products, reduce size of farmland cultivated and reduce the number of labourers employed. This ultimately could lead to low output, inflation and food insecurity. The effects of high cost of labour as found in the study are multiple and affect different farmers differently. Experts (Crane, 2010; Deolaliker and Gaiha, 2012 and Dick et al, 2004) agrees farmers would necessarily make many adjustments in response to increased wages of labourers, which have effect on the quantity of rice produced.

Table 3. Distribution of respondents based on effects of bad road on rice production in the area $\mathrm{N}=110$

\begin{tabular}{|c|c|c|c|c|c|c|}
\hline Variable & SA & $\mathrm{A}$ & $\mathrm{D}$ & SD & $\sum \overline{\mathrm{E}}$ & $\overline{\mathrm{X}}$ \\
\hline Roads in the community are bad & $110(440)$ & - & - & - & 440 & 4.00 \\
\hline \multicolumn{7}{|l|}{$\begin{array}{l}\text { Most farmers cannot access their } \\
\text { farms due to bad road }\end{array}$} \\
\hline $\begin{array}{l}\text { Rice cannot be carried to the market } \\
\text { due to bad road }\end{array}$ & $81(324)$ & $19(57)$ & $10(20)$ & - & 401 & 3.65 \\
\hline Buyers hardly access the community & $60(240)$ & $45(135)$ & - & $5(5)$ & 380 & 3.45 \\
\hline $\begin{array}{l}\text { Rice is sold very cheap as a result of } \\
\text { bad roads }\end{array}$ & $99(396)$ & $9(27)$ & $2(4)$ & - & 427 & 3.83 \\
\hline $\begin{array}{l}\text { The roads are always muddy and } \\
\text { slippery during rainy periods }\end{array}$ & $109(427)$ & $1(3)$ & - & - & 430 & 3.91 \\
\hline $\begin{array}{l}\text { Farmers usually have accidents } \\
\text { trying to convey their products }\end{array}$ & $70(280)$ & $20(60)$ & $12(24)$ & $8(8)$ & 372 & 3.38 \\
\hline $\begin{array}{l}\text { Many farmers have stopped growing } \\
\text { rice due to bad roads }\end{array}$ & $61(244)$ & $30(90)$ & $10(20)$ & $9(9)$ & 363 & 3.3 \\
\hline
\end{tabular}

Source: Field Survey, 2018.

Table 3 shows the distribution of respondents based on effect of bad road on rice production. The result showed that bad roads had a wide range of effects on rice production. Specifically, because of bad roads, many farmers could not access their farms, rice could not be conveyed to the market, rice often sold very cheap, fewer or no buyer comes to the community to buy rice and because of the muddy and unusually slippery nature of the bad roads, farmers often had accidents trying to carry the produce. The implication of this result is that bad roads affect every aspect of rice production - from the point of production (farm) to the point of purchase for consumption (market). According to Chinaka (2015) poverty will continue to be high in rural communities 
because of lack of infrastructure. For example, bad road implies that buyers of farm produce cannot go to the villages and farmers cannot carry their produce to the market. Even when buyers go to the village to buy, for example, rice farmers are usually 'forced' to sell at cheap price. Failure to do so will make the rice remain unsold. This confirms the findings of Braun et al (2009) and Idyrough (2015).

Table 4. Distribution of respondents according to effect of access to commercial bank loan/credit on rice production

\begin{tabular}{|c|c|c|c|c|c|c|}
\hline Variable & SA & $\mathrm{A}$ & $\mathrm{D}$ & SD & $\sum \mathrm{EX}$ & $\overline{\mathrm{X}}$ \\
\hline Farmers hardly access bank loans & $100(400)$ & $10(30)$ & - & - & 430 & 3.91 \\
\hline $\begin{array}{l}\text { Rice farmers do not have collateral } \\
\text { to use for loans }\end{array}$ & $20(80)$ & - & $10(20)$ & $70(70)$ & 170 & 1.55 \\
\hline $\begin{array}{l}\text { Farmers avoid loans due to high } \\
\text { interest rates }\end{array}$ & $110(440)$ & - & - & - & 440 & 4.00 \\
\hline $\begin{array}{l}\text { Rice production is decreasing due to } \\
\text { inadequate credit facilities }\end{array}$ & $40(160)$ & $60(180)$ & $6(12)$ & $4(4)$ & 356 & 3.24 \\
\hline $\begin{array}{l}\text { Lack of access to credit has reduced } \\
\text { rice output. }\end{array}$ & $71(284)$ & $29(87)$ & $8(18)$ & $1(1)$ & 390 & 3.53 \\
\hline $\begin{array}{l}\text { Lack of access to bank loans has } \\
\text { increase farmers poverty }\end{array}$ & $110(440)$ & - & - & - & 440 & 4.00 \\
\hline $\begin{array}{l}\text { Farmers cannot mechanize rice } \\
\text { production due to lack of access to } \\
\text { credit }\end{array}$ & $87(345)$ & $16(43)$ & $4(8)$ & $3(3)$ & $4(2)$ & 3.68 \\
\hline $\begin{array}{l}\text { Farmers cannot purchase inputs } \\
\text { because of lack of access to credit } \\
\text { facilities }\end{array}$ & $100(400)$ & - & $10(20)$ & - & 420 & 3.82 \\
\hline
\end{tabular}

Source: Field Survey, 2018.

Table 4 shows the distribution of respondents based on effect of farmers access to loans on rice production. The results showed that access to loan had multiple effects on rice production in the area. In particular, it was found that farmers hardly have access to bank loans $(\overline{\mathrm{X}}=3.91)$, farmers avoid bank loan because of the high interest rates charged on such loans and because of this limited loan access, rice production is decreasing $(\bar{X}=3.24)$, rice farm holdings are small $(\bar{X}=3.77)$, there is increased poverty due to low income $(\bar{x}=4.00)$, farmers cannot mechanize rice production $(\bar{X}=3.65)$ and it affects farmers' ability to purchase inputs. The implication of this result is that limited loan access by farmers has affected them in various ways, including farming activities, social and economic life and other aspects of life. This result confirms the claims of Dick et al, (2004) that low productivity and farmers' apathy towards farming generally is due to lack of credit facilities, lack of government support and poverty. The result also corroborates Feder et al, (2005) that lack of credit facilities has increased rural poverty, affected the commercialization of agriculture and mechanization of farming operations with resultant low output associated with small farm holding and use of crude implements.

\section{TEST OF HYPOTHESIS}

Table 5. Summary of probit regression result of the effect of socioeconomic characteristics of farmers on rice production

\begin{tabular}{llcc}
\hline Variable & Coefficient & Standard error & t-value \\
Intercept $\left(\mathrm{X}_{0}\right)$ & $-2.38695^{* * *}$ & 1.108944 & -2.20218 \\
Sex of farmers $\left(\mathrm{X}_{1}\right)$ & $0.53438^{*}$ & 0.42449 & 1.2187 \\
Age of farmers $\left(\mathrm{X}_{2}\right)$ & -0.37890 & 0.41817 & -0.90450 \\
Marital status $\left(\mathrm{X}_{3}\right)$ & $0.29596^{* *}$ & 0.16162 & 1.86964
\end{tabular}


International Journal of Advances in Scientific Research and Engineering (ijasre), Vol 5 (7), July-2019

$\begin{array}{llcr}\text { Level of education }\left(\mathrm{X}_{4}\right) & 0.2591 * * * * & 0.08607 & 3.217 \\ \text { Family size }\left(\mathrm{X}_{5}\right) & -0.31921 * * * & 0.19838 & -1.6982 \\ \text { Farm size }\left(\mathrm{X}_{6}\right) & 0.31216^{* *} & 0.15821 & 1.04551 \\ \text { Farming experience }\left(\mathrm{X}_{7}\right) & -0.00121 & 0.03711 & 1.2186 \\ \text { Income }\left(\mathrm{X}_{8}\right) & 0.62119 * & 0.18749 & 1.57622\end{array}$

Source: Field Survey, 2018.

Table 5 shows summary of probit regression result of the effect of socioeconomic characteristics of farmers on rice production in the study area. Eight independent regressing (sex, age, marital status, education, family size, farm size, farming experience and income) were used in assessing rice production output in the study area.

The model was estimated for the full sample of rice farmers, rice production was modeled as a function of a farmer's sex, age, marital status, level education, family size, farm size and income, sex, age, marital status, level education were statistically significant and variously at 5 percent and 10 percent level of significance in determining rice production. The other two variables, age of farmers and farming experience were not significant in influencing rice production. It could be concluded that rice production in the area depends on the farmer's sex, marital status, level of education, family size, farm size and income. This confirms the findings of Lanfier (2009), Malaku (2005) and Ajacro et al (2013) who observed that rice production is influenced by a wide range of farmers' socio-economic characteristics.

A critical look at coefficient $\mathrm{x}_{1}$ (sex of farmers) is 0.5348. This was statistically significant and impacted on rice production in the study area. Coefficient $x_{2}$ (age of farmers) is -0.37791 . This variable was statistically significant but had an inverse relationship with rice production in study area. The coefficient $\mathrm{x}_{3}$ (marital status) is 0.2956 was statistically significant and impacted positively on rice production in the area. Coefficient $\mathrm{x}_{4}$ (level of education) is 0.25917 statistical significant and had a direct relationship with rice production in the area. Coefficient $\mathrm{x}_{5}$ (family size) is -0.31921 was statistically significant at 5 percent but had on inverse relationship with nor production in the area. Coefficient $\mathrm{x}_{1}, \mathrm{x}_{2}$ and $\mathrm{x}_{3}$ (i.e farm size, farming experience and income) is $0.3126,-0.00120$ and 0.62119 ) respectively, $\mathrm{x}_{6}$ and $\mathrm{x}_{7}$ and $\mathrm{x}_{8}$ had a positive relationship with rice production while $\mathrm{x}_{6}$ was statistically insignificant.

\section{CONCLUSION}

Rice is one of the staple foods and most widely consumed food crop in Nigeria. It is produced under diverse ecological conditions but largely in the rural areas. This study has revealed that rice production, regardless of community, is influenced by a wide range of socioeconomic variables such as cost and availability of labour, farmers income and access to credit, sex of farmers, marital status, level of education, family and farm size among others. Improving rice in Calabar Agricultural Zone of Cross River State requires addressing these social and economic challenges particularly enhancing farmers direct access to production resources, including farm inputs, credit and cheap labour.

\section{RECOMMENDATIONS}

The following recommendations were made based on the findings of the study;

- Government should provide micro-credit facilities to rural farmers through loans/grants to strengthen their rice production capabilities.

- $\quad$ Provision of subsidized farm equipment and free tractor services to ease labour cost and commercialize rice production.

- Farmers level of education should be improved through adult literacy programmes such as farmers field schools.

\section{REFERENCES}

2. Adepoju, A. (2000). Issues and recent trends in international migration in sub-Saharan Africa. International Social Science Journal, 52 (165): 383 - 394.

3. Ajaero, K. \& Onokale, P. (2013). The effect of rural-urban migration on rural communities of southern Nigeria. International Journal of Population Research. 61(2): 87 - 93.

4. Appleton, S., Bevan, D. L. Burger, K. \& Willem gunning (2011). Agricultural mechanization. Public services and household Allocation in Africa. Oxford: Oxford University Press. 
5. Awole, S. (2003). Agricultural economics: Foundation and models. Lagos: Evans.

6. Ayalew, K. (2010). Agricultural extension in sub-Saharan Africa. ( $3^{\text {rd }}$ ed). Johannesburg: Leda press.

7. Braun, J. Von, D. Hotchkiss, and M. Immioil (2009). Non-traditional export crops in Guatemala: Effects on production income and nutrition.

8. Chinaka, C. (2015). Economic analysis of small holder rice production for Nigeria Farmers, Extension Bulletin No. 3 National Agricultural Services. Abmadu Bello University Zaria, Nigeria p. 33.

9. Cohen, B. (2015). Urbanization, city growth and the New United Nations development agenda. World Coal Industry Journal, 3(2): $4-7$.

10. Crane, E. (2010). Rice production and mechanization: Science, practice and world resources. Comstock Publishing associates. New York: Cornell University Press.

11. Deolalikar, A. B., \& Gaiha, R. (2012). Targeting of rural public works: Are youths less likely to participate? Paper prepared for a conference on intra-household Resource Allocation: Policy Issues and Research Methods, 12-14 February, International food Policy Research Institute, Washington, DC.

12. Dick, R., Adato M., Hadda, L., \& Hazell, P. (2004). Science and Poverty: An interdisciplinary assessment of the Impact of Agricultural Research. International Food Policy Research Institute, Washington, D.C.

13. Economic News Update (2015). Annual analysis of Nigeria Import-Export. Lagos: forster Printers.

14. Emodi, I. \& Madukew, M. (2008). A review of policies, acts and initiatives in rice innovation system in Nigeria. Journal of Agricultural Extension, 12(2), 77-80.

15. Emukoha, P. S. (2006). Improving labour productivity and technical efficiency in rice production. A Panacea for Poverty reduction in Nigeria. Food Agriculture and Environment, 2(2): 227 - 231.

16. Feder, G., R. E. Just, \& D. Zilberman (2005). Adoption of agricultural innovations in developing countries: A survey Economic Development and Cultural Change 33(22): 255 - 298.

17. Food and Agriculture Organization FAO (2003). Publication your book, Rome.

18. Gannon, C. \& Liu, Z. (2001). Transportation; infrastructure and services, transport and road research laboratory. Washington DC: Pearson.

19. Gregory, N. P. (2000). Agriculture and wealth creation in Africa. New York: Prentice Hall.

20. Harris, F. C. (2015). Migration: Causes and Solutions. (4 ${ }^{\text {th }}$ ed) London: Rutledge.

21. Idyerough, A. (2015). Sociological analysis of social changes in contemporary Africa. Makurdi: Aboki Press.

22. Kato, N. (2014). Modernization and its influence in African Food Supply Systems: An exploratory analysis. International Journal of ethics and life style, 122(2): $31-97$.

23. Laufer, L., (2009). The substitution between upland and swamp rice labour in rural Indian Agricultural production. Discussion paper 472 economic Growth Center: New Haven: Yale University.

24. Malaku, G. (2005). Adoption and profitability of mechanization to upland rice cultivation in Kenya: A study in Ambusel Woreda of Ethiopia. Unpublished M. Sc. Thesis, Almaya University, Alemaya. 